\title{
Assessment of Atmospheric Deposition and Spatial Variability of Trace Metals in Kandy City and Suburbs using Bio-monitoring Technique in Mosses
}

\author{
Lakshika Weerasundara $^{l}$ and Meththika Vithanage ${ }^{2 *}$ \\ ${ }^{1}$ Environmental Chemodynamics Project, National Institute of Fundamental Studies, Kandy, \\ Sri Lanka \\ ${ }^{2}$ Ecosphere Resilience Research Center, Faculty of Applied Sciences, University of Sri \\ Jayewardenepura, Nugegoda, Sri Lanka
}

Date Received 02-01-2018

Date Accepted: 10-11-2018

\begin{abstract}
Deposition of atmospheric Trace metals (TMs) was investigated in this study through the analysis of mosses that have been grown at nine locations within the Kandy Municipal Council area and its suburbs. Hyophila sp. moss was selected for TM analysis with referring their common availability. After cleaning, dried mosses samples were digested with conc. $\mathrm{HNO}_{3}$ in microwave digesting system. Digested samples were analysed for $\mathrm{Al}, \mathrm{Cr}, \mathrm{Mn}, \mathrm{Fe}$, $\mathrm{Ni}, \mathrm{Cu}, \mathrm{Zn}, \mathrm{Cd}$ and $\mathrm{Pb}$ using Inductive Coupled Plasma-Mass Spectrometry (ICP-MS). Average TM concentrations in mosses, were resulted with the order of $\mathrm{Fe}>\mathrm{Al}>\mathrm{Zn}>\mathrm{Mn}>\mathrm{Cu}>$ $\mathrm{Pb}>\mathrm{Cr}>\mathrm{Ni}>\mathrm{Cd}$. The highest and lowest metal concentrations were recorded for $\mathrm{Al}$ and $\mathrm{Cd}$ as 12,150 and $0.2 \mathrm{mg} / \mathrm{kg}$ respectively. Principle factor analysis suggested two major factors; vehicular emission and geographical location, responsible for the TM concentrations in mosses. Factor analysis indicated that approximately about $73 \%$ of the TMs in the atmosphere are by the two factors whereas majority from that to be from the vehicular emission. Apart from that, trans-boundary pollution could identify as one of the major factors for TMs in Kandy. Spatial distributions are not significant for the metals that have identified as geogenic origin and others were reported with clear spatial distribution with having highest accumulations in the areas those experiencing higher traffic activities. The ecosystem risk values are still in the acceptable levels in the means of trace metals in mosses.
\end{abstract}

Key words: $\quad$ mosses, bio-monitoring, trace metals, atmospheric deposition

\section{Introduction}

Atmospheric particulates are dispersed into the environment through either natural or anthropogenic origin. In general, natural contributors are volcanic activities, sea salt aerosol, wind born dust, forest fires and crustal minerals (Karim et al., 2014). Power plants, industries, residential heating and traffic activities are some of major anthropogenic activities that rich with particulate emission (Cao et al., 2011, Weerasundara and Vithanage, 2015). As most of the anthropogenic activities are gathered in urban cities, the urban environments are great victims of these atmospheric pollutants (Cao et al., 2011). The atmospheric particulates which

*Correspondence: meththika@sjp.ac.lk

(C) University of Sri Jayewardenepura 
are emitted from various sources are rich with different types of atmospheric pollutants that are able to affect both human and ecosystem quality (Castillo et al., 2013). Among them, trace metals (TMs) are one of the most important pollutants in urban atmosphere (Azimi et al., 2003, Weerasundara and Vithanage, 2015). It is acknowledged that some of these TMs such as $\mathrm{Ni}, \mathrm{Mn}, \mathrm{Cu}, \mathrm{Fe}$ and $\mathrm{Zn}$ are essential to various biochemical and physiological functions in living organisms (He et al., 2005). However, exceed of the threshold levels would cause different detrimental health effects (Jaishankar et al., 2014). Although the atmospheric pollution by TMs is acknowledged in all over the world, the pollution status has increasing trend due to escalation of emission sources and therefore, monitoring and quantification of TM loads in the atmospheric deposition is a vital need in this era.

The physicochemical methods that facilitate direct collection are the most extensively employed methods to quantification of TMs in atmospheric deposition (Attanayaka and Wijeyaratne, 2013). However, due to high cost and extensively required time and space, the studies on atmospheric deposition quantification were limited (Azimi et al., 2003, Ares et al., 2012). Despite of above limitations, the physicochemical methods are also failed to implement the possible effects of various pollutants on living organisms (Attanayaka and Wijeyaratne, 2013). Bio-monitoring is an inexpensive method that can be used to determine the levels pollution through atmospheric deposition over specific locations (Singh et al., 2017). Common occurrence in the field, the easiness of sampling, the degree of trace element accumulation and no expensive technical equipment is required are some of remarkable advantages on bio-monitors over physicochemical monitors (Singh et al., 2017, Ares et al., 2012). Notably, this concept of bio-monitoring brings an opportunity to assess the effects on pollutants on biotic components in an ecosystem (Attanayaka and Wijeyaratne, 2013).

Although there are several organisms such as ferns, grass, tree rings and pine needles had been used as bio-monitors, their mechanisms are still not fully understood. Lichen, mosses and tree barks have been the most frequent bio-monitoring surfaces for TMs over last few decades (De Bruin, 1990). Moss bio-monitoring has been believed as much advantageous as it is bearing less technical and analytical problems (Barandovski et al., 2008). Most of moss species are capable to grow under different environmental conditions even in urban and industrial areas. Therefore, the sampling of the same species is easy even for geographically disparate areas (Ares et al., 2012). Due to lack of epidermis and cuticle, metal ions can be easily penetrated through cell wall and it enhances the accumulation of metals in a passive way facilitating ion exchange mechanisms (Ares et al., 2012, Onianwa, 2001, Chakrabortty and Paratkar, 2006). As a result of absence of vascular system, the transport of minerals between moss segments is rather confined. The lack of root system promotes the independent nature in the means of mineral uptake and therefore it expedites the accomplishment of nutrient requirements through atmospheric deposition. Hence, the mosses have been identified as one of the most effective organism to assess TM concentrations in atmospheric deposition (Aničić et al., 2009,Onianwa, 2001, Boquete et al., 2014). Table 1 show the selected studies which have been focused on TM bio-monitoring through mosses. 
Table 1: Different studies focused on heavy metal bio-monitoring through mosses and their concentrations.

\begin{tabular}{|c|c|c|c|c|c|c|c|c|c|c|c|c|}
\hline $\begin{array}{l}\text { City and } \\
\text { Country }\end{array}$ & Nature of the sampling site & Moss species & $\begin{array}{l}\text { Al } \\
\mathrm{mg} / \mathrm{kg}\end{array}$ & $\begin{array}{l}\mathrm{Cr} \\
\mathrm{mg} / \mathrm{kg}\end{array}$ & $\begin{array}{l}\text { Mn } \\
\mathrm{mg} / \mathrm{kg}\end{array}$ & $\begin{array}{l}\mathrm{Fe} \\
\mathrm{mg} / \mathrm{kg}\end{array}$ & $\begin{array}{l}\mathrm{Cu} \\
\mathrm{mg} / \mathrm{kg}\end{array}$ & $\begin{array}{l}\mathrm{Ni} \\
\mathrm{mg} / \mathrm{kg}\end{array}$ & $\begin{array}{l}\text { Zn } \\
\mathrm{mg} / \mathrm{kg}\end{array}$ & $\begin{array}{l}\text { Cd } \\
\mathrm{mg} / \mathrm{kg}\end{array}$ & $\begin{array}{l}\mathrm{Pb} \\
\mathrm{mg} / \mathrm{kg}\end{array}$ & Reference \\
\hline Eket, Nigeria & $\begin{array}{l}\text { High vehicular traffic, airstrip, municipal } \\
\text { waste burning }\end{array}$ & Racopilum africanum & & 5.8 & 113.2 & & 18.1 & 6.4 & 87.7 & 0.002 & 16.7 & Ite et al. (2014) \\
\hline Ibeno, Nigeria & $\begin{array}{l}\text { Industrial power generation, gas flaring } \\
\text { and venting }\end{array}$ & Calymperes erosum & & 4.4 & 59.3 & & 9.6 & 2.1 & 0.01 & 0.05 & 0.001 & Ite et al. (2014) \\
\hline $\begin{array}{l}\text { Kosovo, } \\
\text { Southeastern } \\
\text { Europe }\end{array}$ & $\begin{array}{l}\text { Away from main roads or building, high } \\
\text { mountain area }\end{array}$ & $\begin{array}{l}\text { Pseudocleropodium } \\
\text { purum, Hypnum } \\
\text { cupressiforme }\end{array}$ & & 2.7 & 92.7 & 570 & 3.12 & 6.6 & 37.4 & 0.3 & 12.1 & $\begin{array}{l}\text { Maxhuni et al. } \\
\text { (2016) }\end{array}$ \\
\hline Albania, Europe & $\begin{array}{l}\text { A hotspot for trace metals contamination } \\
\text { in Europe }\end{array}$ & $\begin{array}{l}\text { Hypnum cupressiforme, } \\
\text { Pseudoscleropodium } \\
\text { purum }\end{array}$ & $1800^{*}$ & & & $2000^{*}$ & & & & & & Lazo et al. (2018) \\
\hline $\begin{array}{l}\text { Alameda, } \\
\text { Mexico }\end{array}$ & $\begin{array}{l}\text { Mexican highlands located in Mexican } \\
\text { central area, a valley area, High } \\
\text { population density, Industrial area }\end{array}$ & Fabronia ciliaris & & 33.34 & 172 & 9332 & 32.12 & 10.88 & 145 & & 112 & $\begin{array}{l}\text { Zarazúa-Ortega et } \\
\text { al. (2013) }\end{array}$ \\
\hline $\begin{array}{l}\text { Reforma, } \\
\text { Mexico }\end{array}$ & $\begin{array}{l}\text { Mexican highlands located in Mexican } \\
\text { central area, a valley area, High } \\
\text { population density, Industrial area }\end{array}$ & Fabronia ciliaris & & 27.21 & 119 & 6746 & 40.20 & 11.08 & 179 & & 107 & $\begin{array}{l}\text { Zarazúa-Ortega et } \\
\text { al. (2013) }\end{array}$ \\
\hline Hipico, Mexico & $\begin{array}{l}\text { Mexican highlands located in Mexican } \\
\text { central area, a valley area, High } \\
\text { population density, Industrial area }\end{array}$ & Fabronia ciliaris & & 22.32 & 132 & 5616 & 26.17 & 7.40 & 151 & & 32.60 & $\begin{array}{l}\text { Zarazúa-Ortega et } \\
\text { al. (2013) }\end{array}$ \\
\hline Pila, Mexico & $\begin{array}{l}\text { Mexican highlands located in Mexican } \\
\text { central area, a valley area, High } \\
\text { population density, Industrial area }\end{array}$ & Fabronia ciliaris & & 19.93 & 161 & 6432 & 20.68 & 6.20 & 136 & & 25.31 & $\begin{array}{l}\text { Zarazúa-Ortega et } \\
\text { al. (2013) }\end{array}$ \\
\hline
\end{tabular}

${ }^{*}$ Approximate values 
Since Kandy City of Sri Lanka is the second largest of the country and the vehicle traffic is significant, in Kandy City due to touristic and geographic nature and hence the traffic influence is crucial for emission of TMs into the atmosphere (Weerasundara et al., 2017). In accordance with the results shown in Weerasundara et al. (2017) both geogenic and anthropogenic metal have been found in the Kandy environment whereas the geogenic metal concentrations showed elevated concentrations than that of the anthropogenic metals. However, it has been stated that the traffic activities are the foremost reason for emitting both of those metal types into the atmosphere either as primary or secondary emission. Thus, the monitoring of TM concentrations in atmospheric deposition is a need in order to identify the present status, mitigation strategies and control policies. Hence, the present study was conducted to monitor and assess the atmospheric TM deposition in Kandy City through mosses as bio-monitoring tools. Weerasundara et al. (2017) has depict the data for atmospheric deposition through deposition collection and it facilitates the understanding of present status of the Kandy area in the means of atmospheric TM deposition and the present study facilitates the understanding of amount of TMs which been accumulated with the surface area of the living organisms for a long time period.

\section{Materials and methods}

\subsection{Study area and sampling sites}

The sampling sites were located within and the suburbs of the $26 \mathrm{~km}^{2}$ Kandy City which is centrally located in a small valley facilitating thermal inversions within the city atmosphere (Weerasundara et al., 2017). Four main entrances are allowing more than 106,000 of vehicles as daily traffic flow. Due to significant vehicular volume within a small area, it always creates immense traffic congestion especially in office hours and weekends. The permanent population in Kandy is more than 170,000 people and the daily transient population is around 100,000 people (Wickramasinghe et al., 2011). The city is located at $\sim 500 \mathrm{~m}$ above mean sea level. The average day time ambient temperature is in the range of $28-32{ }^{\circ} \mathrm{C}$, monthly rainfall is in the range of $52-398 \mathrm{~mm}$ and the day time relative humidity is in the range of $63-83 \%$ (Weerasundara et al., 2017).

Twelve sampling sites were selected for the collection of mosses samples However, only nine sample sites were consisted with the selected moss species. Both inner City and suburbs were considered while selecting of sampling sites. These sites were designated as Good Shed station $\left(\mathrm{S}_{1}\right)$, Railway station $\left(\mathrm{S}_{2}\right)$, Market place $\left(\mathrm{S}_{3}\right)$, Children's park $\left(\mathrm{S}_{4}\right)$, Kingswood college $\left(\mathrm{S}_{5}\right)$, Pushpadana College $\left(\mathrm{S}_{6}\right)$, Trinity College $\left(\mathrm{S}_{7}\right)$, High school $\left(\mathrm{S}_{8}\right)$, National Institute of Fundamental Studies (NIFS) $\left(S_{9}\right)$, Thannekumbura $\left(S_{10}\right)$, Lewalla $\left(S_{11}\right)$, Peradeniya $\left(S_{12}\right)$ (Fig. 1). Lewalla is a site far away from main road and the vehicular activities. Therefore it was selected as the control site. 


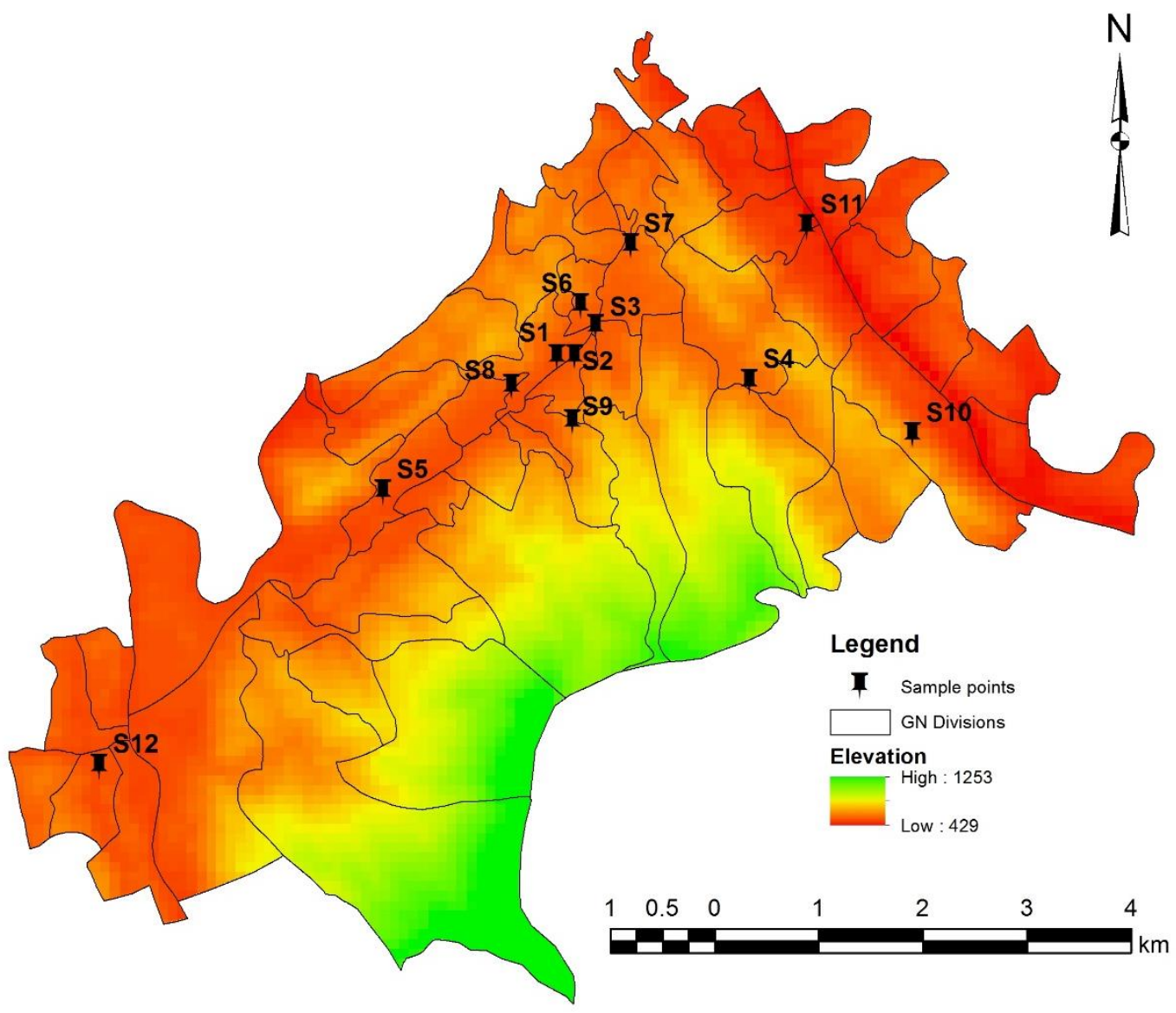

Figure 1: Map of the study area and locations of the twelve sampling sites. $\mathrm{S}_{1}=$ Good Shed Station; $\mathrm{S}_{2}=$ Railway Station; $\mathrm{S}_{3}=$ Market Place; $\mathrm{S}_{4}=$ Children's Park; $\mathrm{S}_{5}=$ Kingswood College; $\mathrm{S}_{6}=$ Pushpadana College; $\mathrm{S}_{7}=$ Trinity College; $\mathrm{S}_{8}=$ High School;

$\mathrm{S}_{9}=$ National Institute of Fundamental Studies; $\mathrm{S}_{10}=$ Thannekumbura; $\mathrm{S}_{11}=$ Lewalla; $\mathrm{S}_{12}=$ Peradeniya

\subsection{Sampling of mosses}

Hyophila Sp. moss (Fig. 2) samples were collected from nine sampling sites. Only top portion was collected, discarding the basal portion with adhered soil or impervious surfaces. In each location, sampling was done at 2-3 individual places and mixed to form a common sample. These moss samples were collected into clear paper bags and sealed immediately and brought into the laboratory and stored in a refrigerator until analysis. At the laboratory, the mosses samples were cleaned by carefully removing any adhered particles. Then those were further cleaned with deionized water and magnetic starrier. Same procedure was followed for three times to clean the mosses to the greatest extend. After cleaning, the mosses samples were oven dried for 24 hour at $40{ }^{\circ} \mathrm{C}$ and they were ground to a fine powder using a pre-cleaned mortar and pestle. 


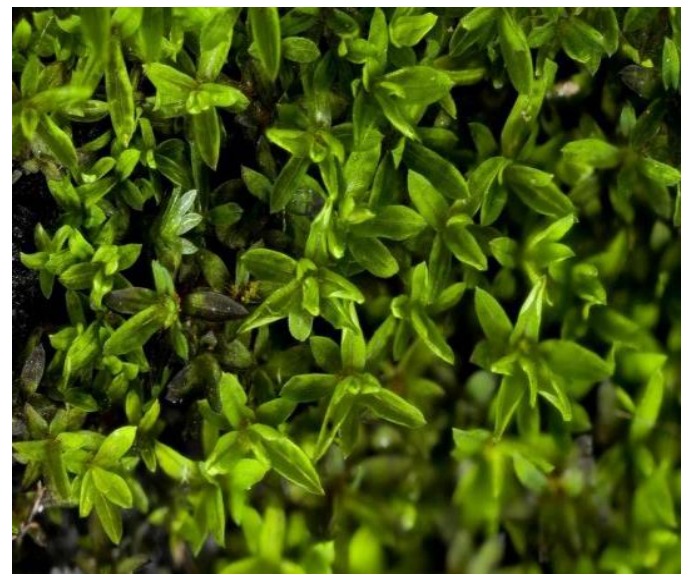

Figure 2: Hyophila Sp. Moss.

\subsection{Laboratory analysis}

Powdered moss samples of $0.2 \mathrm{~g}$ were acid digested with $5 \mathrm{ml}$ of Analytical grade Conc. $\mathrm{HNO}_{3}$. It was conducted with a MARS6 microwave digestion system (CEM cooperation). All the digestion vessels were cleaned with Conc. $\mathrm{HNO}_{3}$ before every digestion circles. After completion of a digestion, the vessels were allowed to cool and opened under a fume hood. The entire sample was transferred into a $25 \mathrm{ml}$ volumetric flask and the volume was adjusted with de-ionized water. The sample was then filtered with a $0.45 \mu \mathrm{m}$ membrane filter and kept in a refrigerator under $4^{\circ} \mathrm{C}$ until the metal analysis has been taken placed. The digested samples were analyzed for TMs namely, $\mathrm{Al}, \mathrm{Cr}, \mathrm{Mn}, \mathrm{Fe}, \mathrm{Ni}, \mathrm{Cu}, \mathrm{Zn}, \mathrm{Cd}$ and $\mathrm{Pb}$ because those metals are commonly present in the urban environments. Since Al is a crustal element, it was selected as an identifier of geogenic metals (Weerasundara et al., 2017). The TM concentrations were determined using as Agilent 8800 Triple Quadruple Inductively coupled plasma mass spectrometer (ICP-MS) at Queensland University of Technology (QUT), Australia. All the quality assurance and quality control (QA/QC) samples were prepared and tested as specified in US EPA method 200.8 (USEPA, 1994). Calibration curves were setup and ensured that the residual mean square $\left(\mathrm{R}^{2}\right)$ was greater than or equal to 0.98 . Consequently, certified reference material (CRM) recovery was compared against values given in standard certificate. Multielement standard solution V for ICP-MS prepared by TraceCERT® was used as the CRM. Calibration blank was a volume of deionized water acidified with the same acid matric as the calibration standards. Internal standards were prepared according to the US EPA method 200.8 (USEPA, 1994). The diluted internal standard was spiked into the samples at $5 \mu \mathrm{g} / \mathrm{L}$ prior to the ICP-MS analysis to ensure all the samples are above the method detection limits as described in US EPA method 200.8 (USEPA, 1994).

\subsection{EnricTMent Factor (EF) analysis}

The EF analysis was conducted to determine either anthropogenic or terrestrial influence upon TMs for their enricTMents using Eq. (1) developed by Zarazúa-Ortega et al.( 2013). Iron was selected as conservative element to determine the enricTMent of TMs. The values for reference soil, coming from a site that far away from anthropogenic activities. 


$$
E F=\frac{\left(C_{s} / F e_{s}\right)_{\text {moss or lichen value }}}{\left(C_{o} / F e_{o}\right)_{\text {reference soil value }}}
$$

Where, $\mathrm{M}_{\mathrm{s}}$ is concentration of one particular metal in moss sample, $\mathrm{Fe}_{\mathrm{s}}$ is concentration of selected conservative reference element $(\mathrm{Fe})$ in moss sample, $\mathrm{M}_{\mathrm{o}}$ is concentration of same metal in reference soil, and $\mathrm{Fe}_{\mathrm{o}}$ is concentration of conservative reference element in reference soil. In order to assess the enricTMent level by metal, following criteria in Table 2 were applied.

Table 2: Criteria for evaluated moss enricTMent factor.

\begin{tabular}{cl}
\hline EnricTMent Factor value & \multicolumn{1}{c}{ EnricTMent level } \\
\hline$\leq 2$ & Conservative \\
$3-5$ & Slightly enriched \\
$6-9$ & Moderately enriched \\
$\geq 10$ & Highly enriched \\
\hline
\end{tabular}

\subsection{Ecological risk assessment of trace metals}

Accumulating coefficients of TMs in mosses samples taken from different sampling sites were computed and applied to indicate the accumulating status of TM in the mosses samples. The computing equation for accumulating coefficient $\mathrm{C}_{\mathrm{f}}$ is as follows

$$
C_{f}^{i}=\frac{C_{m}^{i}}{C_{n}^{i}}
$$

Where, $C_{m}^{i}$ is the value of TM concentration in the samples, and $C_{n}^{i}$ is the background values $(\mathrm{mg} / \mathrm{kg})$.

The potential ecological risk index method developed by Hakanson was applied in this study (Zhu et al., 2012) to assess the ecological risk. According to this method, the potential ecological risk coefficient $\mathrm{E}_{\mathrm{r}}^{\mathrm{i}}$ of a single element and the potential ecological risk index, $\mathrm{R}_{\mathrm{i}}$ of multi-element were computed via the following equations (Equation 3 and 4)

$$
\begin{aligned}
& E_{r}^{i}=T_{f}^{i} \times C_{f}^{i} \\
& R_{i}=\sum_{i=1}^{n} E_{r}^{i}
\end{aligned}
$$


Where, $\mathrm{C}_{\mathrm{f}}^{\mathrm{i}}$ is the accumulating coefficient of a particular element and $\mathrm{T}_{\mathrm{f}}^{\mathrm{i}}$ is the toxic-response factor of that particular element (which reflects its toxicity levels and the sensitivity of bioorganism to it). $E_{r}^{i}$ is the potential risk of individual $T M$ and $R_{i}$ is the sum of potential risk of individual TM. The indices and grades for $\mathrm{E}_{\mathrm{r}}^{\mathrm{i}}$ and $\mathrm{R}_{\mathrm{i}}$ as follows.

01. For $\mathrm{E}_{\mathrm{r} \text {, }}^{\mathrm{i}}$
a. $\mathrm{E}_{\mathrm{r}}^{\mathrm{i}}<40$ : $\quad$ Low risk
b. $40 \leq \mathrm{E}_{\mathrm{r}}^{\mathrm{i}}<80 \quad$ = Moderate risk
c. $80 \leq \mathrm{E}_{\mathrm{r}}^{\mathrm{i}}<160 \quad=$ Considerable risk
d. $160 \leq \mathrm{E}_{\mathrm{r}}^{\mathrm{i}}<320=$ High risk
e. $320 \leq \mathrm{E}_{\mathrm{r}}^{\mathrm{i}} \quad$ = Very high risk

02. For $R_{i}$
a. $\mathrm{R}_{\mathrm{i}}<150 \quad=$ Low risk
b. $150 \leq \mathrm{R}_{\mathrm{i}}<300=$ Moderate risk
c. $300 \leq \mathrm{R}_{\mathrm{i}}<600=$ Considerable risk
d. $600 \leq \mathrm{R}_{\mathrm{i}} \quad$ = Very high risk

\section{Results and discussion}

\subsection{Metal concentrations in mosses}

It was not found the Hyophila sp. moss was not found in all of 12 sampling points and therefore, TM concentrations in mosses are available only for sampling sites namely, $S_{1}, S_{2}, S_{5}$, $\mathrm{S}_{6}, \mathrm{~S}_{7}, \mathrm{~S}_{9}, \mathrm{~S}_{10}, \mathrm{~S}_{11}$ and $\mathrm{S}_{12}$. The mean TM concentrations, SDs and ranges reported in moss samples are illustrated in Table 3. The wide range variation and higher SD values are also reported with mosses. The metal concentrations in mosses for twelve sample sites are presented in Fig. 3. Al and Fe are the mostly found TMs in moss samples over nine sampling sites. Kandy district is mainly consisted with Reddish Brown Lateritic soil. In this Reddish Brown Lateritic soil, all of the all soil profiles are consist with clay; A1 - 0-6 inches, fine gravely clay loam; A36-10 inches, fine and coarse gravelly clay loam; B2t - 10-37 inches, fine and coarse gravely clay (Moorman and Panabokke, 1961). The clay minerals in soil are layered alumino-silicate (Tennakoon, 1987). Therefore, the sources identification for $\mathrm{Al}$ and $\mathrm{Fe}$ would be geogenic origin with the presence of Alumino-silicate based earth crust in Kandy area. Mn and Zn also reported in significant concentrations in moss samples. Other TMs namely $\mathrm{Cr}, \mathrm{Ni}, \mathrm{Cu}, \mathrm{Cd}$ and $\mathrm{Pb}$ are in comparatively lower concentrations while $\mathrm{Cd}$ showed lowest concentrations in moss samples.

For mosses the Pearson's correlation coefficient values were found to be in higher values for most of TM pairs indicating significant relationships among them (Table 4). The similarity for of their sources of origins would be the reason for this increased coefficient values. The PCA applied for grouping of separate statistically significant associations for mosses. From the nine analyzed variables, the matrix of dominant rotated factor loadings for mosses is presented in Table 5. Two major factors were identified and interpreted as Factor 1 and Factor 2, which include $83 \%$ of the variability of tested elements. 
Factor 1 ( $\mathrm{Al}, \mathrm{Cr}, \mathrm{Mn}, \mathrm{Fe}, \mathrm{Ni}, \mathrm{Cu}$ and $\mathrm{Pb})$

The factor 1 associates TMs indicate anthropogenic influence in the studied area. As Kandy city having high traffic activities due to historical and economic importance, these vehicular activities would be the major anthropogenic source for these metals. The city is lacking with significant industrial activities and any other significant anthropogenic activities such as mining the vehicular activities play a major role for the emission of anthropogenic metals into the atmosphere. Except for $\mathrm{Pb}$ all other metals in this factor have factor loadings more than $90 \%$. The major source for emission of $\mathrm{Pb}$ is leaded gasoline. However at present, the leaded gasoline is banded and the emissions have been limited. However it may not completely removed from the urban environment as previously emitted $\mathrm{Pb}$ are still persistent and circulating through the atmosphere. This fact would be the reason for $\mathrm{Pb}$ has such low but significant factor loading within this factor.

\section{Factor $2(\mathrm{Zn}, \mathrm{Cd}$ and $\mathrm{Pb})$}

The metals associated in this factor are not generally originated from geogenic sources. Therefore this factor cannot be indicated as a geogenic factor. The outside factor such as transboundary pollution through wind activities would be the sources for this metals in mosses collected in Kandy area.

Table 3: Descriptive statistics for metal concentrations in mosses

\begin{tabular}{crrc}
\hline \multirow{2}{*}{ Metal } & \multicolumn{3}{c}{ Concentrations in Mosses (mg/kg) } \\
\cline { 2 - 4 } & Mean & SD & Range \\
\hline $\mathrm{Al}$ & 11181.6 & 5770.7 & $5836.3-25869.1$ \\
$\mathrm{Cr}$ & 41.6 & 19.3 & $25.3-89.8$ \\
$\mathrm{Mn}$ & 348.5 & 178.8 & $186.4-806$ \\
$\mathrm{Fe}$ & 21745.9 & 14021.8 & $12150.5-58.84 .2$ \\
$\mathrm{Ni}$ & 23.9 & 24.4 & $12.9-88.8$ \\
$\mathrm{Cu}$ & 58 & 26.9 & $35.1-123.8$ \\
$\mathrm{Zn}$ & 357.3 & 162.1 & $198.1-666.4$ \\
$\mathrm{Cd}$ & 0.9 & 0.8 & $0.2-2.8$ \\
$\mathrm{~Pb}$ & 26.2 & 11.1 & $12.8-45.8$ \\
\hline
\end{tabular}

$\mathrm{SD}=$ Standard Deviation

The special distribution of metals reported in moss samples are showed in Fig. 4. As Al is mainly from geogenic sources, the distribution pattern is common for all of sampling sites. Therefore $\mathrm{Al}$ has not sharp spatial distribution except for $\mathrm{S}_{6}$ site. In $\mathrm{S}_{6}$ site, the Al concentrations have huge increase rather that all other sampling sites. Not only for $\mathrm{Al}$ but also for $\mathrm{Cr}, \mathrm{Mn}, \mathrm{Fe}$, $\mathrm{Ni}$ and $\mathrm{Cu}, \mathrm{S}_{6}$ site has been showed quite high concentrations indicating the site $\mathrm{S}_{6}$ is highly affected with atmospheric deposition. For $\mathrm{Zn}$, the concentrations are comparatively high in sites $\mathrm{S}_{10}$ and $\mathrm{S}_{11} . \mathrm{Zn}$ is highly concentrated in site $\mathrm{S}_{2}, \mathrm{~S}_{7}, \mathrm{~S}_{9}$ and $\mathrm{S}_{12}$. Regarding $\mathrm{Pb}$, the depositions do not depict sharp spatial variation. 

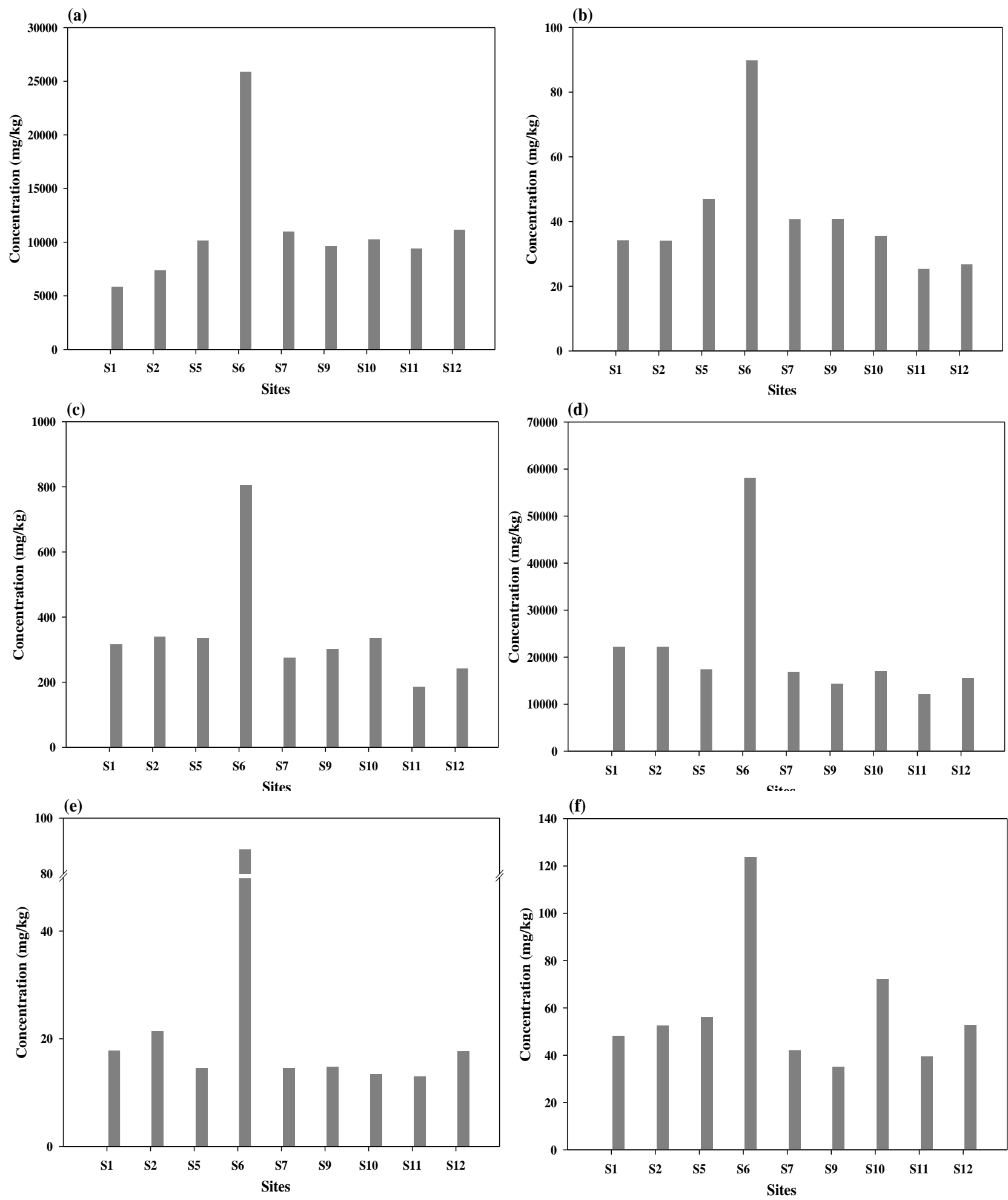

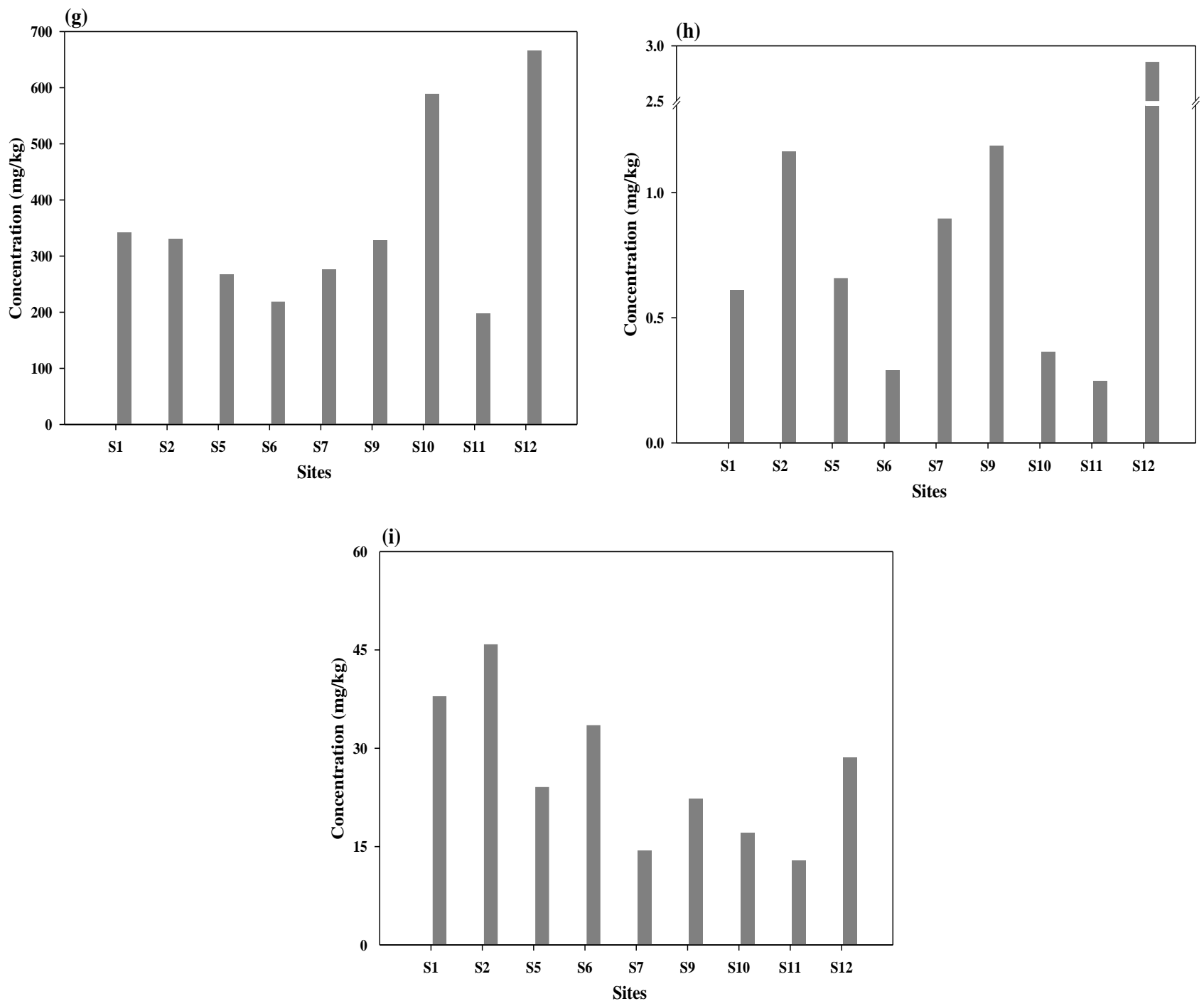

Figure"4: Metal loads in mosses samples. (a) $\mathrm{Al}$, (b) $\mathrm{Fe}$, (c) $\mathrm{Zn}$, (d) $\mathrm{Cr}$, (e) $\mathrm{Mn}$, (f) $\mathrm{Ni}$, (g) $\mathrm{Cu}$, (h) $\mathrm{Cd}$, and (i) $\mathrm{Pb}$ at nine sampling locations

Table 4: Correlation coefficient values for heavy metal pairs.

\begin{tabular}{|c|ccccccccc|}
\hline & Al & Cr & Mn & Fe & Ni & $\mathbf{C u}$ & $\mathbf{Z n}$ & $\mathbf{C d}$ & $\mathbf{P b}$ \\
\cline { 2 - 9 } $\mathbf{A l}$ & & & & & & & & & \\
$\mathbf{C r}$ & 0.90 & & & & & & & & \\
$\mathbf{M n}$ & 0.88 & 0.96 & & & & & & & \\
$\mathbf{F e}$ & 0.87 & 0.92 & 0.98 & & & & & & \\
$\mathbf{N i}$ & 0.93 & 0.92 & 0.96 & 0.98 & & & & & \\
$\mathbf{C u}$ & 0.88 & 0.86 & 0.93 & 0.92 & 0.91 & & & \\
$\mathbf{Z n}$ & -0.21 & -0.40 & -0.27 & -0.30 & -0.30 & -0.05 & & \\
$\mathbf{C d}$ & -0.18 & -0.36 & -0.32 & -0.29 & -0.24 & -0.29 & 0.64 & & \\
$\mathbf{P b}$ & 0.02 & 0.20 & 0.36 & 0.42 & 0.34 & 0.26 & 0.01 & 0.20 & \\
\hline
\end{tabular}


Table 5: Matrix of rotated factor loadings for trace metals in mosses $(\mathrm{F}>0.5)$.

\begin{tabular}{cccc}
\hline Metal & $\begin{array}{c}\text { Factor 1 } \\
(\%)\end{array}$ & $\begin{array}{c}\text { Factor 2 } \\
(\%)\end{array}$ & $\begin{array}{c}\text { Communality } \\
(\%)\end{array}$ \\
\hline $\mathrm{Al}$ & 91 & -12 & 84 \\
$\mathrm{Cr}$ & 94 & -25 & 94 \\
$\mathrm{Mn}$ & 99 & -10 & 98 \\
$\mathrm{Fe}$ & 99 & -8 & 98 \\
$\mathrm{Ni}$ & 98 & -8 & 97 \\
$\mathrm{Cu}$ & 95 & -1 & 89 \\
$\mathrm{Zn}$ & -21 & 82 & 71 \\
$\mathrm{Cd}$ & -21 & 87 & 80 \\
$\mathrm{~Pb}$ & 40 & 47 & 37 \\
\hline
\end{tabular}

Enrichment Factor analysis in mosses

Table 6 depicts the EF values for moss samples collected from nine sampling sites. Regarding $\mathrm{Al}, \mathrm{Cr}$ and $\mathrm{Mn}$ most of the sites are in conservative and slightly enriched levels and therefore, those TMs may primarily coming from the geogenic origin. However, the vehicular activities may have some effect re-suspension of those TMs. The PCA analysis also has proved this fact. Other metals; $\mathrm{Ni}, \mathrm{Cu}, \mathrm{Zn}, \mathrm{Cd}$ and $\mathrm{Pb}$ have reached moderately to highly enriched levels within the sampling sites. Therefore, those metals may have significant anthropogenic involvement as it has confirmed by PCA analysis.

Table 6: Mosses enrichment factor values from sample sites at Kandy City and suburbs.

\begin{tabular}{ccccccccccc}
\hline $\begin{array}{c}\text { Meta } \\
\mathbf{l}\end{array}$ & $\mathbf{S}_{\mathbf{1}}$ & $\mathbf{S}_{\mathbf{2}}$ & $\mathbf{S}_{\mathbf{5}}$ & $\mathbf{S}_{\mathbf{6}}$ & $\mathbf{S}_{\mathbf{7}}$ & $\mathbf{S}_{\mathbf{9}}$ & $\mathbf{S}_{\mathbf{1 0}}$ & $\mathbf{S}_{\mathbf{1 1}}$ & $\mathbf{S}_{\mathbf{1 2}}$ & $\begin{array}{c}\text { Mean } \\
\mathbf{E F}\end{array}$ \\
\hline $\mathrm{Al}$ & $7 \mathrm{E}-06$ & $8 \mathrm{E}-06$ & $1 \mathrm{E}-05$ & $1 \mathrm{E}-05$ & $2 \mathrm{E}-05$ & $1 \mathrm{E}-05$ & $1 \mathrm{E}-05$ & $4 \mathrm{E}-05$ & $4 \mathrm{E}-06$ & $1 \mathrm{E}-05$ \\
$\mathrm{Cr}$ & 4 & 3 & 6 & 5 & 5 & 4 & 5 & 4 & 4 & 4 \\
$\mathrm{Mn}$ & 5 & 5 & 7 & 3 & 5 & 4 & 5 & 4 & 5 & 5 \\
$\mathrm{Ni}$ & 6 & 6 & 6 & 6 & 6 & 6 & 5 & 7 & 7 & 6 \\
$\mathrm{Cu}$ & 11 & 11 & 15 & 10 & 12 & 11 & 20 & 31 & 12 & 15 \\
$\mathrm{Zn}$ & 10 & 9 & 9 & 6 & 10 & 8 & 19 & 16 & 14 & 11 \\
$\mathrm{Cd}$ & 1227 & 1096 & 879 & 552 & 1301 & 1146 & 876 & 1931 & 3446 & 1384 \\
$\mathrm{~Pb}$ & 22 & 24 & 16 & 18 & 10 & 18 & 12 & 17 & 15 & 17 \\
\hline
\end{tabular}

\section{Ecological risk assessment in mosses}

Table 7 shows the average potential ecological risk $\left(\mathrm{E}_{\mathrm{r}}^{\mathrm{i}}\right)$ values for individual TMs of moss samples. All most all the $\mathrm{E}_{\mathrm{r}}^{\mathrm{i}}$ values indicate less than 40, presenting low ecological risk. Therefore the results show that still the ecosystem health in Kandy area is in acceptable levels in the means of atmospheric trace metals on biological organisms. 
Table 7: Average ecological risk $\left(\mathrm{E}_{\mathrm{r}}^{\mathrm{i}}\right)$ values for nine trace metals on moss samples.

\begin{tabular}{cccc}
\hline Metal & \multicolumn{2}{c}{ Concentration $(\mathrm{mg} / \mathrm{kg})$} & $\mathrm{E}_{\mathrm{r}}^{\mathrm{i}}$ value \\
\hline $\mathrm{Cr}$ & Min & 9.1 & 0.6 \\
& Max & 47.0 & 3.3 \\
& Mean & 33.2 & 2.2 \\
\hline $\mathrm{Mn}$ & Min & 56.3 & 0.1 \\
& Max & 339.9 & 1.1 \\
& Mean & 226.1 & 0.7 \\
\hline $\mathrm{Ni}$ & Min & 5.8 & 3.0 \\
& Max & 21.3 & 11.0 \\
& Mean & 15.2 & 7.7 \\
\hline $\mathrm{Cu}$ & Min & 35.1 & 0.4 \\
& Max & 72.2 & 0.8 \\
& Mean & 47.9 & 0.6 \\
\hline $\mathrm{Zn}$ & Min & 136.9 & 0.4 \\
& Max & 530.5 & 1.0 \\
& Mean & 290.5 & 0.7 \\
\hline $\mathrm{Cd}$ & Min & 0.2 & 0.4 \\
& Max & 1.2 & 2.3 \\
& Mean & 0.5 & 0.9 \\
\hline $\mathrm{Pb}$ & Min & 7.4 & 0.5 \\
& Max & 45.8 & 3.6 \\
& Mean & 24.6 & 1.9 \\
\hline & & & \\
\hline
\end{tabular}

\section{Conclusions}

Hyophila sp. mosses were collected from selected nine sampling sites within Kandy City and its suburbs and analysed for a range of TMs. As for TMs Al and Fe, from geogenic sources, were found to be in significantly higher concentrations in mosses samples compared to the other TMs. As the $\mathrm{Fe}$ and $\mathrm{Al}$ are mainly from geogenic origin the increased concentrations suggest the influence of soil particles to the atmospheric deposition in Kandy and its suburbs. Zn and Mn have ranked in next two highest concentrations. Zn can be originated from various anthropogenic sources. The traffic related activities are always promoting $\mathrm{Zn}$ emission to the atmosphere with galvanized automobile parts. Galvanized roofing materials are another possible source for this increased $\mathrm{Zn}$ concentrations since galvanized roofing materials are common in Kandy area. The other TMs investigated, namely, $\mathrm{Cr}, \mathrm{Ni}, \mathrm{Cu}, \mathrm{Cd}$ and $\mathrm{Pb}$, were attributed to being primarily originating from anthropogenic sources, mainly from traffic activities as confirmed by the PCA analysis undertaken. The trans-boundary pollution may have some influence on low concentrated TMs in Kandy area in particular for Cd. The special distribution showed similar patterns for the TMs that identified as geogenicaly originates and the TMs which have significant anthropogenic influence showed clear special variation among sampling sites. Most importantly, the areas that have considerable traffic activities showed elevated metal concentrations. As Kandy City has historical and religious importance, large numbers of tourists and devotees visit the City. Therefore, the traffic conditions are higher. Within the City, at different locations, there are variations in metal concentrations and the major contributor for this special variation could be the traffic intensities. However, still the city in in acceptable ecological risk levels in the means on trace metals. 

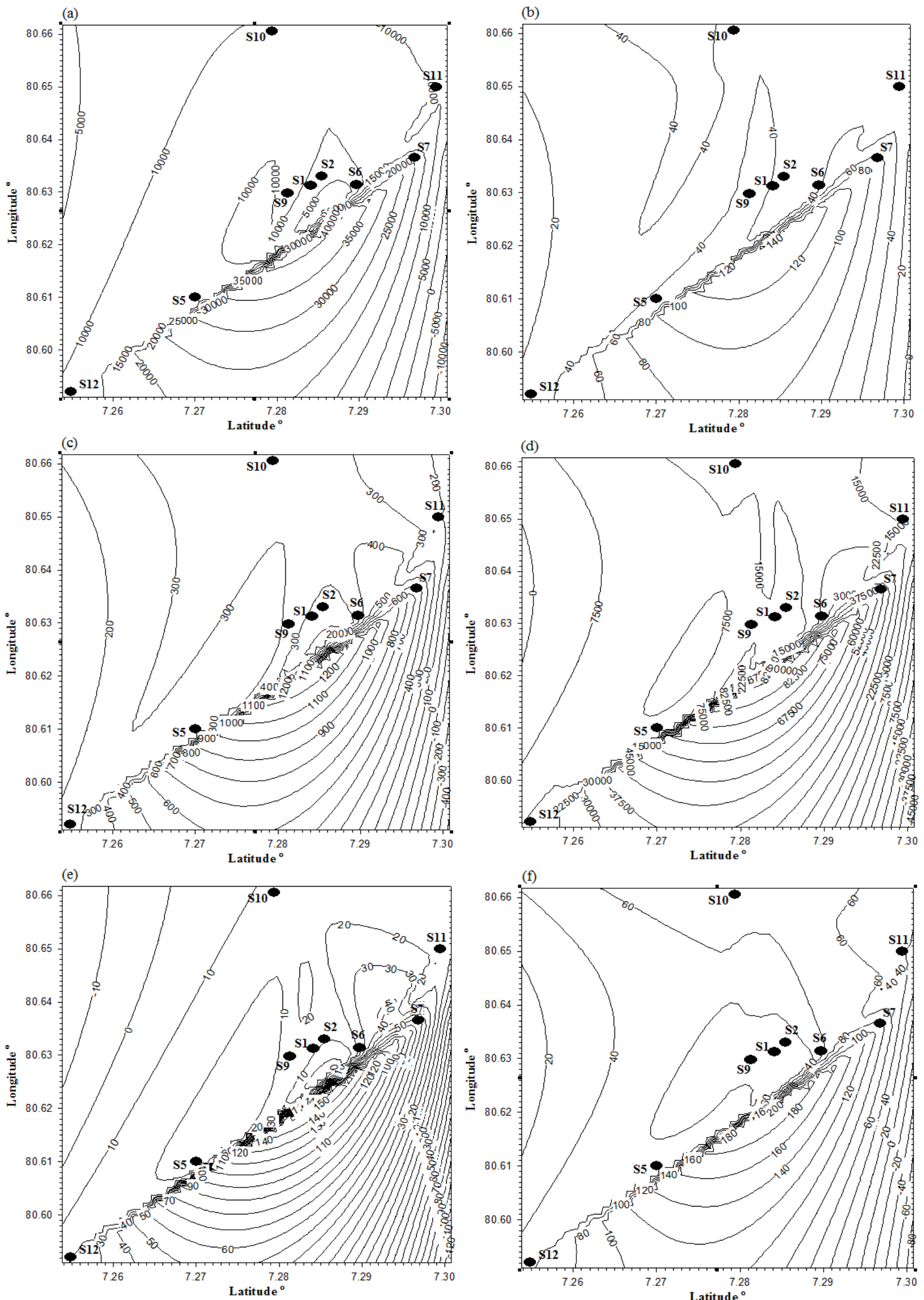

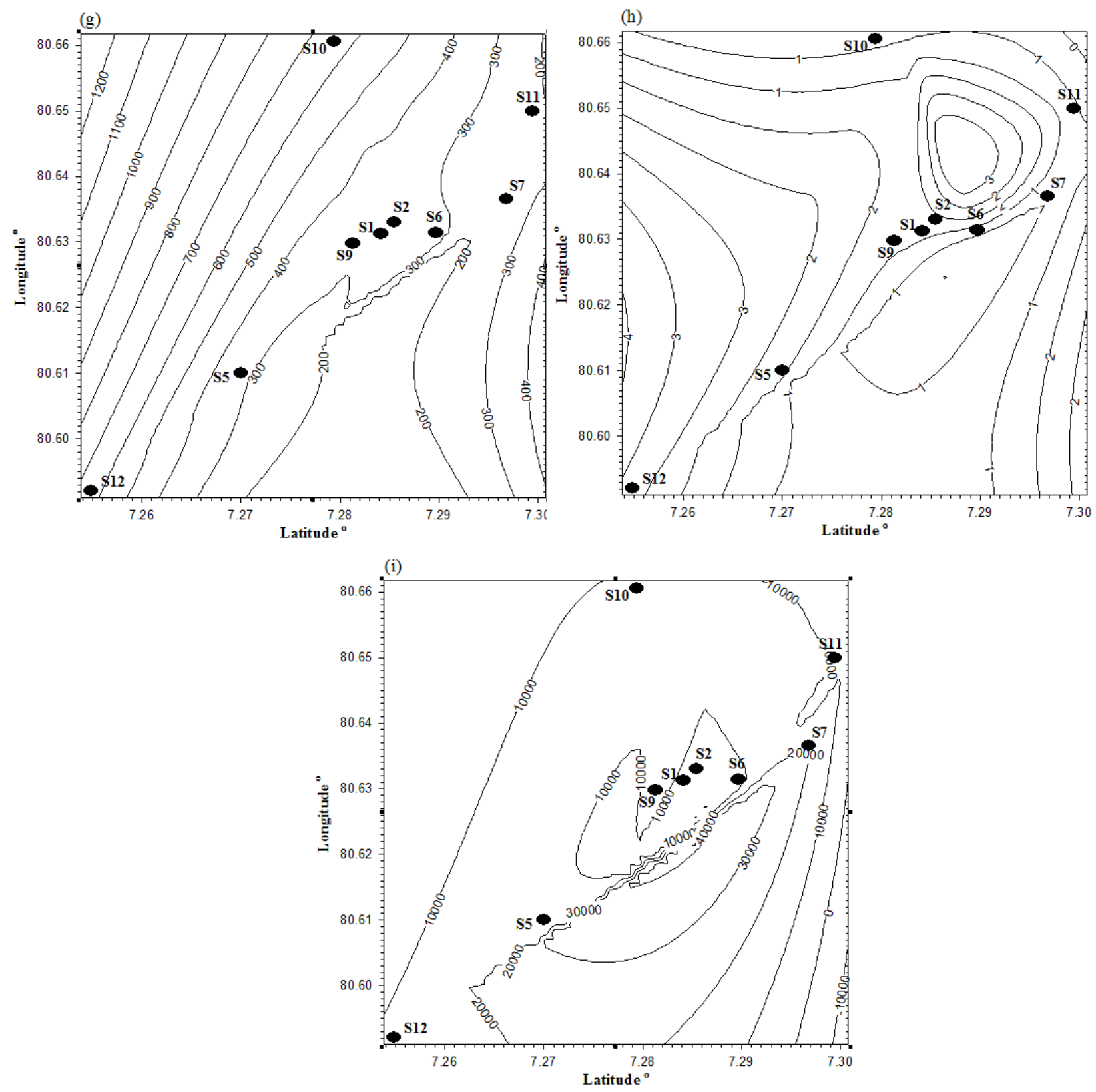

Figure 4: Spatial distribution of heavy metal for moss in Kandy and its environs.

(a) Cr, (b) Al, (c) Mn, (d) Fe, (e) Ni, (f) Cu, (g) Zn, (h) Cd, and (i) Pb; Good shed station ( $\mathrm{S}_{1}$ ), Railway station $\left(\mathrm{S}_{2}\right)$, Kingswood college $\left(\mathrm{S}_{5}\right)$, Pushpadana College $\left(\mathrm{S}_{6}\right)$, Trinity College $\left(\mathrm{S}_{7}\right)$, National Institute of Fundamental Studies (NIFS) $\left(\mathrm{S}_{9}\right)$, Thannekumbura $\left(\mathrm{S}_{10}\right)$, Lewalla $\left(\mathrm{S}_{11}\right)$, Peradeniya $\left(\mathrm{S}_{12}\right)$

\section{Acknowledgement}

The authors wish acknowledge The National Science Foundation (NSF), Sri Lanka, for providing funding for undertaking this research study (Grant number RG/2014/EB/03). Prof. Ashantha Goonetilleke (QUT, Australia), for his contribution on heavy metal analysis and Prof. 
Siril Wijesundara, (National Institute of Fundamental Studies, Kandy, Sri Lanka) and Ms. Nadeeka Gunasekara, (Royal Botanical Garden, Peradeniya, Sri Lanka), for their assistance on species identification of moss.

\section{References}

Aničić M., Tasić M., Frontasyeva M., et al. 2009. Active moss biomonitoring of trace elements with Sphagnum girgensohnii moss bags in relation to atmospheric bulk deposition in Belgrade, Serbia. Environmental Pollution, 157: 673-679.

Ares A., Aboal J., Carballeira A., et al. 2012. Moss bag biomonitoring: a methodological review. Science of the Total Environment, 432: 143-158.

Attanayaka A.,Wijeyaratne S.C. 2013. Corticolous lichen diversity, a potential indicator for monitoring air pollution in tropics. Journal of the National Science Foundation of Sri Lanka, 41: 131-140.

Azimi S., Ludwig A., Thévenot D.R., et al. 2003. Trace metal determination in total atmospheric deposition in rural and urban areas. Science of the Total Environment, 308: 247-256.

Barandovski L., Cekova M., Frontasyeva M., et al. 2008. Atmospheric deposition of trace element pollutants in Macedonia studied by the moss biomonitoring technique. Environmental Monitoring and Assessment, 138: 107-118.

Boquete M., Aboal J., Carballeira A., et al. 2014. Effect of age on the heavy metal concentration in segments of Pseudoscleropodium purum and the biomonitoring of atmospheric deposition of metals. Atmospheric Environment, 86: 28-34.

Cao Z., Yang Y., Lu J., et al. 2011. Atmospheric particle characterization, distribution, and deposition in Xi'an, Shaanxi Province, Central China. Environmental Pollution, 159: 577-584.

Castillo S., Jesús D., De La Campa A.M.S., et al. 2013. Heavy metal deposition fluxes affecting an Atlantic coastal area in the southwest of Spain. Atmospheric Environment, 77: 509517.

Chakrabortty S., Paratkar G.T. 2006. Biomonitoring of trace element air pollution using mosses. Aerosol and Air Quality Research, 6: 247-258.

De Bruin M. 1990. Applying biological monitors and neutron activation analysis in studies of heavy-metal air pollution. IAEA Bulletin, 32: 22-27.

He Z.L., Yang X.E., Stoffella P.J. 2005. Trace elements in agroecosystems and impacts on the environment. Journal of Trace elements in Medicine and Biology, 19: 125-140.

Ite AE, Udousoro I.I., Ibok U.J. 2014. Distribution of some atmospheric trace metals in lichen and moss samples collected from Eket and Ibeno Local Government Areas of Akwa Ibom State, Nigeria. American journal of Environmental protection, 2: 22-31.

Jaishankar M., Tseten T., Anbalagan N., et al. 2014. Toxicity, mechanism and health effects of some trace metals. Interdisciplinary toxicology, 7: 60-72.

Karim Z., Qureshi B.A., Mumtaz M., et al. 2014. Heavy metal content in urban soils as an indicator of anthropogenic and natural influences on landscape of Karachi: A multivariate spatio-temporal analysis. Ecological indicators, 42: 20-31.

Lazo P., Steinnes E., Qarri F., et al. 2018. Origin and spatial distribution of metals in moss samples in Albania: a hotspot of heavy metal contamination in Europe. Chemosphere, 190: 337-349. 
Maxhuni A., Lazo P., Kane S., et al. 2016. First survey of atmospheric heavy metal deposition in Kosovo using moss biomonitoring. Environmental Science and Pollution Research, 23: 744-755.

Moorman F., Panabokke C. 1961. Soils of Ceylon. Tropical Agriculture, 117: 22-23.

Onianwa P. 2001. Monitoring atmospheric metal pollution: A review of the use of mosses as indicators. Environmental Monitoring and Assessment, 71: 13-50.

Singh S., Srivastava K., Gahtori D., et al. 2017. Bryomonitoring of Atmospheric Elements in Rhodobryum giganteum (Schwaegr.) Par., Growing in Uttarakhand Region of Indian Himalayas. Aerosol and Air Quality Research, 17: 810-820.

Tennakoon D. 1987. Some aspects of the chemistry of clay minerals.

Usepa 1994. Metod 200.8: Trace elements in waters and wastes by inductively coupled plasmamass spectrometry. Washington, DC, US Environmental Protection Agency.

Weerasundara L., Amarasekara R., Magana-Arachchi D., et al. 2017. Microorganisms and trace metals associated with atmospheric deposition in a congested urban environment of a developing country: Sri Lanka. Science of the Total Environment, 584: 803-812.

Weerasundara L., Vithanage M. 2015. The challenge of vehicular emission and atmospheric deposition: From air to water.

Wickramasinghe A., Karunaratne D., Sivakanesan R. 2011. PM 10-bound polycyclic aromatic hydrocarbons: concentrations, source characterization and estimating their risk in urban, suburban and rural areas in Kandy, Sri Lanka. Atmospheric Environment, 45: 2642-2650.

Zarazúa-Ortega G., Poblano-Bata J., Tejeda-Vega S., et al. 2013. Assessment of spatial variability of trace metals in metropolitan zone of toluca valley, Mexico, using the biomonitoring technique in mosses and TXRF analysis. The Scientific World Journal.

Zhu H.N., Yuan X.Z., Zeng G.M., et al. 2012. Ecological risk assessment of trace metals in sediments of Xiawan Port based on modified potential ecological risk index. Transactions of Nonferrous Metals Society of China, 22: 1470-1477. 